\title{
Inhibition of Heme Polymerization In Vitro Assay of Extract of Sirih Leaf (Piper Betle Linn.) and Sunflower Leaves (Helianthus Annuus L.)
}

\author{
Ami Tjitraresmi*, Yasmiwar Susilawati, Moelyono Moektiwardoyo
}

Fakultas Farmasi, Universitas Padjadjaran, Jatinangor, Indonesia

\begin{abstract}
Submitted 23 December 2019; Revised 7 January 2020; Accepted 22 January 2020; Published 3 February 2020
\end{abstract}
*Corresponding author: ami.tjitraresmi@unpad.ac.id

\begin{abstract}
Malaria is a disease that occurs in tropical countries like Indonesia. The incidence of malaria in the world is still quite high and the occurrence of cases of Plasmodium resistance to antimalarial drugs and the widespread of resistance have prompted researchers to look for new antimalarial drugs, especially from natural materials. The people of Indonesia have long used betel leaf (Piper betle Linn.) and sunflower leaf (Helianthus annuus L.) as an antimalarial drug. The purpose of this study was to determine antimalarial activity through inhibition of heme polymerization and determine secondary metabolite compounds by phytochemical screening from betel leaves and sunflower leaves. The heme polymerization inhibition activity assay was carried out by the in vitro method using a microplate reader at $415 \mathrm{~nm}$ and $630 \mathrm{~nm}$ wavelengths. $\mathrm{IC}_{50}$ values of betel leaf extract and sunflower leaf were $178.67 \mu \mathrm{g} / \mathrm{ml}$ and $160.10 \mu \mathrm{g} / \mathrm{ml}$, respectively. Phytochemical screening results from betel leaf showed the presence of flavonoids, polyphenols, tannins, quinones, saponins, and monoterpenoidssesquiterpenoids, while sunflower leaves contain alkaloids, polyphenols, flavonoids, steroids and monoterpenoids-sesquiterpenoids.
\end{abstract}

Keywords: antimalarial, Helianthus annuus L., heme polymerization, Piper betle Linn.

\section{Aktivitas Penghambatan Polimerisasi Heme Secara In Vitro Ekstrak Daun Sirih (Piper Betle Linn.) dan Daun Bunga Matahari (Helianthus Annuus L.)}

\begin{abstract}
Abstrak
Malaria adalah penyakit yang ada di negara tropis seperti Indonesia. Angka kejadian malaria di dunia yang masih cukup tinggi dan terjadinya kasus resistensi Plasmodium terhadap obat antimalaria serta penyebaran resistensi yang meluas telah mendorong para peneliti untuk mencari obat antimalaria baru yang lebih efektif terutama dari bahan alam. Daun sirih (Piper betle Linn.) dan daun bunga matahari (Helianthus annuus L.) telah lama digunakan oleh masyarakat Indonesia sebagai obat antimalaria. Tujuan dari penelitian ini adalah untuk mengetahui aktivitas antimalaria melalui penghambatan polimerisasi heme dan mengetahui senyawa metabolit sekunder dengan penapisan fitokimia dari daun sirih dan daun bunga matahari. Uji aktivitas penghambatan polimerisasi heme dilakukan dengan metode in vitro dengan menggunakan microplate reader pada panjang gelombang $415 \mathrm{~nm}$ dan $630 \mathrm{~nm}$. Nilai $\mathrm{IC}_{50}$ dari ekstrak daun sirih dan daun bunga matahari berturut-turut sebesar 178,67 $\mu \mathrm{g} / \mathrm{ml}$ dan 160,10 $\mu \mathrm{g} / \mathrm{ml}$. Hasil penapisan fitokimia dari daun sirih menunjukkan adanya senyawa flavonoid, polifenol, tannin, kuinon, saponin, dan monoterpenoid-seskuiterpenoid, sedangkan daun bunga matahari mengandung senyawa alkaloid, polifenol, flavonoid, steroid dan monoterpenoid-sesquiterpenoid.
\end{abstract}

Kata Kunci: antimalaria, Helianthus annuus L., Piper betle Linn., polimerisasi heme 


\section{Pendahuluan}

Malaria adalah penyakit yang disebabkan oleh parasit Plasmodium. Parasit menyebar ke manusia melalui gigitan nyamuk Anopheles sp. betina yang terinfeksi, yang disebut sebagai "vektor malaria". ${ }^{1,2}$

Penularan malaria banyak ditemukan di daerah tropis dan subtropis, karena di daerah ini nyamuk Anopheles dapat bertahan dan berkembang biak. Namun di negara endemis malaria penularan malaria tidak terjadi di seluruh wilayah negara baik daerah tropis maupun subtropis, dikarenakan transmisi tidak akan terjadi pada daerah dengan ketinggian yang sangat tinggi, selama musim dingin, dan di beberapa negara di mana transmisi telah terganggu melalui program pengendalian malaria. ${ }^{3}$

Pengendalian penyakit malaria membutuhkan pendekatan terpadu, termasuk pencegahan (terutama pengendalian vektor) dan pengobatan dengan senyawa antimalaria yang efektif. Sejak edisi pertama pedoman untuk pengobatan malaria oleh WHO pada tahun 2006, negara yang merupakan daerah endemik $P$. falciparum telah memperbarui kebijakan pengobatan mereka dari penggunaan monoterapi dengan obat-obatan seperti klorokuin, amodiaquine dan sulfadoxine-pirimetamin (SP) ke terapi kombinasi berbasis artemisinin (ACT) yang saat ini direkomendasikan. ACT umumnya sangat efektif dan ditoleransi dengan baik. Ini telah memberikan kontribusi besar pada pengurangan morbiditas dan mortalitas global akibat malaria. ${ }^{4}$

Saat ini resistensi Plasmodium falciparum terhadap obat-obatan antimalaria menjadi masalah terutama di daerah endemik. ${ }^{5}$ Hal ini dapat meningkatkan morbiditas dan mortalitas akibat malaria. Resistensi terjadi terutama karena adanya mutasi pada gen dari Plasmodium. ${ }^{6}$ Banyaknya kasus resistensi Plasmodium terhadap obat malaria digunakan saat ini, serta penyebaran resistensi yang meluas telah mendorong para peneliti untuk mencari obat antimalaria baru yang lebih efektif. $^{4}$

Plasmodium sp. mendegradasi hemoglobin dalam eritrosit inang untuk menggunakan produk katabolik yang dihasilkan sebagai sumber asam amino selama masa perkembangan dan proliferasi. Proses degradasi hemoglobin juga disertai dengan pelepasan heme bebas. Heme bebas bersifat aktif secara oksidatif serta bersifat toksik bagi sel inang dan parasit malaria, dan menyebabkan kematian parasit. Karena tidak adanya enzim heme oksigenase, parasit tidak dapat memotong heme menjadi tetrapyrrole rantai terbuka, yang diperlukan untuk ekskresi seluler. Untuk melindungi dirinya, parasit mendetoksifikasi heme bebas melalui netralisasi dengan protein yang kaya histidin, degradasi dengan reduksi glutation, atau kristalisasi menjadi hemozoin, yang merupakan pigmen malaria yang tidak larut dalam air yang diproduksi dalam vakuola makanan. Klorokuin dan obat antimalaria yang telah terbukti menghambat pembentukan kristal heme sintetik, $\beta$-hematin, yang secara memiliki struktur yang identik dengan hemozoin, dan menghambat pembentukan hemozoin dalam vakuola makanan parasit malaria. Saat ini uji aktivitas inhibisi pembentukan $\beta$-hematin berguna dalam mengidentifikasi beberapa anti malaria baru atau untuk penapisan aktivitas antimalaria.,

Penggunaan obat tradisional dan herbal merupakan pilihan alternatif untuk pengobatan di negara-negara endemik malaria, seperti Indonesia. Hal ini dikarenakan Indonesia merupakan salah satu negara terbesar yang kaya akan keanekaragaman hayati serta biota laut. Selain itu, mayoritas masyarakat Indonesia masih menggunakan tanaman sebagai obat tradisional karena dipercaya memiliki khasiat sebagai obat. ${ }^{9}$

Tumbuhan yang secara empiris digunakan sebagai obat malaria di Indonesia diantaranya adalah daun sirih (Piper betle Linn.) dan daun bunga matahari (Helianthus annuus L.). ${ }^{10}$ Tumbuhan sirih (Piper betle Linn.) dalah tumbuhan yang termasuk ke dalam suku Piperaceae. Tumbuhan ini paling banyak dibudidayakan di wilayah Asia Selatan dan Asia Tenggara. ${ }^{11}$ Uji aktivitas antimalaria secara in vivo ekstrak metanol daun sirih pada mencit yang diinfeksi oleh Plasmodium berghei menunjukkan hasil bahwa pada dosis 
ekstrak methanol daun sirih 50, 100, 200 dan $400 \mathrm{mg} / \mathrm{kg}$ secara berurutan menghasilkan penurunan kadar parasitemia sebesar 37,50\%, $45,83 \%, 66,46 \%$ dan $70,63 \% .^{12}$ Tumbuhan bunga matahari (Helianthus annuus L.) adalah tumbuhan yanga termasuk ke dalam suku Asteraceae. Uji aktivitas antimalaria secara in vitro terhadap Plasmodium falciparum 3D7 menunjukkan bahwa IC50 ekstrak metanol daun bunga matahari adalah $22,18 \mathrm{mg} / \mathrm{mL}$ sedangkan $\mathrm{IC}_{50}$ fraksi etil asetatnya adalah sebesar $16,68 \mathrm{mg} / \mathrm{mL} .{ }^{13}$ Walaupun pengujian aktivitas antimalaria dari kedua tumbuhan ini sudah dilakukan akan tetapi aktivitas antimalaria dengan mekanisme penghambatan polimerisasi heme belum diketahui.

\section{Metode}

\subsection{Alat}

Maserator, rotavapor (Buchi), plate 96 sumuran (NEST), mikropipet (Thermo), microplate reader $(\mathrm{EPOCH})$, alat gelas yang biasa digunakan di laboratorium fitokimia.

\subsection{Bahan}

Bahan yang digunakan dalam penelitian ini adalah daun sirih (Piper betle Linn.) dan daun bunga matahari (Helianthus annuus L.) yang diperoleh dari daerah Bandung, Jawa Barat, etanol, hemein klorida (SIGMA), dimetil sulfoksida (DMSO) (MERCK), Tween 20 (MERCK), buffer asetat $1 \mathrm{M} \mathrm{(pH}$ $4,8)$.

\subsection{Prosedur Penelitian}

\subsubsection{Ekstraksi}

Ekstraksi dilakukan terhadap daun sirih (Piper betle Linn.) dan daun bunga matahari (Helianthus annuus L.) yang telah dikeringkan. Ekstraksi dilakukan dengan menggunakan metode maserasi menggunakan pelarut etanol $70 \%$ selama $3 \times 24$ jam dengan penggantian pelarut setiap 24 jam. Ekstrak etanol ditampung dan dikisatkan dengan menggunakan rotary evaporator dan disimpan di atas penangas air dengan suhu $60^{\circ} \mathrm{C}$ hingga mencapai berat konstan.

\subsubsection{Penapisan fitokimia}

Penapisan fitokimia dilakukan terhadap simplisia tumbuhan dengan menggunakan metode Farnsworth, ${ }^{14}$ yang dimodifikasi.

\section{A. Alkaloid}

Bahan yang akan diuji dibasakan dengan amonia 1\% kemudian ditambahkan kloroform. Lapisan kloroform diambil dan ditempatkan pada tabung reaksi. Ke dalam filtrat ditambahkan $\mathrm{HCl} 1 \mathrm{~N}$ kemudian dikocok kuat dan didiamkan hingga terjadi pemisahan. Lapisan asam dipipet dan dibagi menjadi tiga bagian pada tabung reaksi berbeda. Tabung reaksi 1 ditambahkan larutan pereaksi Dragendorf, tabung reaksi 2 ditambahkan pereaksi Mayer dan tabung reaksi 3 digunakan sebagai blanko. Hasil positif dapat dilihat dari terbentuknya endapan merah kecoklatan pada tabung 1 dan endapan putih pada tabung 2 .

B. Polifenol

Bahan dimasukanke dalam tabungreaksi yang berisi aquades kemudian dipanaskan di atas penangas air selama beberapa menit lalu disaring. Filtrat diambil kemudian ditambahkan pelarut besi (III) klorida. Hasil positif dapat dilihat dari terbentuknya warna biru kehitaman pada larutan.

\section{Flavonoid}

Bahan dimasukan ke dalam tabung reaksi yang berisi aquades kemudian dipanaskan di atas penangas air selama beberapa menit lalu disaring. Filtrat diambil dan ditambahkan serbuk $\mathrm{Mg}$ dan $\mathrm{HCl} 2 \mathrm{~N}$. $\mathrm{Ke}$ dalam larutan kemudian ditambahkan amil alkohol lalu campuran dikocok kuat. Campuran didiamkan selama beberapa menit hingga terpisah. Hasil positif ditandai dengan terbentuknya warna kuning hingga merah yang dapat ditarik oleh amil alkohol.

\section{Monoterpenoid dan seskuiterpenoid}

Bahan digerus dengan menggunakan eter. Filtrat diambil kemudian diuapkan hingga kering. Ke dalam residu diteteskan vanilin $10 \%$ dalam $\mathrm{H}_{2} \mathrm{SO}_{4}$ pekat. Terbentuknya warna-warna menunjukkan adanya senyawa monoterpen dan seskuiterpen.

E. Steroid dan triterpenoid

Bahan digerus dengan menggunakan eter. Filtrat diambil kemudian diuapkan hingga kering. Ke dalam residu diteteskan pereaksi Lieberman-Burchard. Adanya 
senyawa golongan triterpenoid ditunjukkan dengan terbentuknya warna ungu sedangkan senyawa golongan steroid ditandai dengan terbentuknya warna biru kehijauan.

F. Kuinon

Bahan dimasukan ke dalam tabung reaksi yang berisi aquades kemudian dipanaskan di atas penangas air selama beberapa menit lalu disaring. Filtrat diambil kemudian ditambahkan larutan $\mathrm{KOH} 5 \%$. Hasil positif dapat dilihat dari terbentuknya warna kuning hingga merah pada larutan.

\section{G. Tanin}

Bahan dimasukan ke dalam tabung reaksi yang berisi aquades kemudian dipanaskan di atas penangas air selama beberapa menit lalu disaring. Filtrat diambil dan ditetesi larutan gelatin 1\%. Hasil positif dapat dilihat dari terbentuknya endapan putih pada larutan.

\section{H. Saponin}

Bahan dimasukan ke dalam tabung reaksi yang berisi aquades kemudian dipanaskan di atas penangas air selama beberapa menit lalu disaring. Filtrat diambil kemudian dikocok kuat secara vertikal selama sepuluh hingga dua puluh detik. Keberadaan senyawa saponin ditunjukkan dengan terbentuknya busa persisten setelah pendiaman selama kurang lebih sepuluh menit atau setelah penambahan asam klorida.

\subsubsection{Uji aktivitas penghambatan polimerisasi} heme secara in vitro

Penapisan aktivitas antimalaria dilakukan terhadap 10 ekstrak tumbuhan uji secara in vitro dengan metode inhibisi polimerisasi heme atau metode Huy et al, ${ }^{15}$ yang dimodifikasi. Pengujian antimalaria dilakukan dengan tahapan penelitian:

A. Sebanyak 16,3 $\mathrm{mg}$ hemin klorida dilarutkan dalam $1 \mathrm{~mL}$ dimetil sulfoksida(DMSO) lalu disaring dengan membran filter berdiameter $0,2 \mu \mathrm{m}$.

B. Sebanyak $22,2 \mu \mathrm{L}$ larutan hemin klorida dalam DMSO dilarutkan dengan buffer asetat $1 \mathrm{M}(\mathrm{pH} 4,8)$ sampai $5 \mathrm{~mL}$. Larutan ini dipakai sebagai larutan hemin uji.

C. Sebanyak masing-masing $20 \mu \mathrm{L}$ larutan uji berupa ekstrak daun sirih, ekstrak daun bunga matahari dan ekstrak kulit batang kina sebagai pembanding, dengan masing-masing konsentrasi akhir sebesar 31,$25 ; 62,5$; $125 ; 250$ dan $500 \mu \mathrm{g} / \mathrm{mL}$ dimasukkan ke dalam plate 96 sumuran.

D. Kemudian ditambahkan sebanyak masing-masing $90 \mu \mathrm{L}$ larutan hemin uji dan reaksi polimerisasi heme dimulai dengan menambahkan larutan Tween-20 (konsentrasi akhir 0,02 $\mathrm{mg} / \mathrm{mL}$ ).

E. Plate kemudian diinkubasi pada suhu $37^{\circ} \mathrm{C}$ selama 250 menit untuk selanjutnya dibaca serapannya pada panjang gelombang 415 dan $630 \mathrm{~nm}$ menggunakan microplate reader (EPOCH). Fraksi heme yang diubah menjadi $\beta$-hematin dihitung berdasarkan persamaan: ${ }^{15}$

$\mathrm{f}=\left(\mathrm{A}_{\text {kontrol }}-\mathrm{A}_{\text {sampel }}\right) /\left(\mathrm{A}_{\text {kontrol }}-\mathrm{A}_{\text {min }}\right)$

Keterangan:

$\mathrm{A}_{\text {kontrol }}=$ nilai serapan heme tanpa Tween-20 atau ekstrak uji $\mathrm{A}_{\text {sampel }}=$ serapan heme dengan penambahan Tween-20 dan ekstrak uji $\mathrm{A}_{\min }=$ serapan heme dengan penambahan Tween-20 tanpa ekstrak uji

$\mathrm{f}=$ fraksi heme yang diubah menjadi $\beta$-hematin Persentase penghambatan pembentukan $\beta$-hematin oleh ekstrak uji ataupunpembandingekstrakkulitbatang kina dihitung berdasarkan persamaan: ${ }^{15}$

Penghambatan $=(1-f) \times 100 \%$

Keterangan:

$\mathrm{f}=$ fraksi heme yang diubah menjadi $\beta$-hematin

F. Data diolah menggunakan analisa probit antara log konsentrasi larutan uji (x) dengan persentase inhibisi (y) sehingga diperoleh nilai $\mathrm{IC}_{50}$.

\section{Hasil}

3.1. Ekstraksi

Rendemen ekstrak kental yang diperoleh dari hasil ekstraksi dengan metode 
Tabel 1. Hasil penapisan fitokimia simplisia daun sirih dan daun bunga matahari

\begin{tabular}{lcc}
\hline \multicolumn{1}{c}{ Golongan senyawa metabolit } & Daun sirih & Daun bunga matahari \\
\hline Alkaloid & - & + \\
Flavonoid & + & + \\
Polifenolat & + & + \\
Tanin & + & - \\
Kuinon & + & - \\
Saponin & + & - \\
Steroid/ triterpenoid & + & + \\
Monoterpenoid/ seskuiterpenoid & + & + \\
\hline
\end{tabular}

maserasi menggunakan pelarut etanol $70 \%$ adalah $17,3 \%$ untuk ekstrak daun sirih dan $14 \%$ untuk ekstrak daun bunga matahari.

\subsection{Penapisan fitokimia}

Hasil penapisan fitokimia dari simplisia daun sirih (Piper betle Linn.) dan daun bunga matahari (Helianthus annuus L.) dapat dilihat pada Tabel 1.

\subsection{Uji aktivitas penghambatan polimerisasi} heme secara in vitro

Hasil uji aktivitas penghambatan polimerisasi heme secara in vitro terhadap ekstrak etanol daun sirih dan ekstrak etanol daun bunga matahari dapat dilihat pada Tabel 2.

\section{Pembahasan}

\subsection{Ekstraksi}

Ekstrak kental sirih yang diperoleh berwarna hijau dan memiliki yang khas, sedangkan ekstrak daun bunga matahari berwarna hijau dan tidak berbau khas.

\subsection{Penapisan fitokimia}

Kuinin adalah senyawa alkaloid yang merupakan obat malaria pertama yang diisolasi dari Cinchona sp. ${ }^{16,17}$ dan artemisinin adalah senyawa seskuiterpen yang saat ini direkomendasikan oleh WHO sebagai obat malaria. ${ }^{18}$ Berdasarkan hasil penapisan fitokimia terhadap kedua bahan tumbuhan uji maka terlihat adanya senyawa monoterpenoid dan seskuiterpenoid dari daun sirih dan daun bunga matahari sedangkan senyawa alkaloid terdapat pada daun bunga matahari. Pan et al, ${ }^{19}$ melaporkan bahwa pada kurun waktu 2001-
2017 ada sekitar 175 senyawa antimalaria yang diperoleh dari tumbuhan dan ada sekitar 25 senyawa antimalaria yang diperoleh dari alga. Aktivitas antimalaria dari berbagai ekstrak tumbuhan biasanya dihasilkan dari berbagai macam golongan metabolit sekunder, seperti alkaloid, terpenoid, iridoid, cardenolides, flavonoid, kumarin, senyawa fenolat, poliasetilen, xanton, kuinon, steroid, lignin, tanin dan saponin.

\subsection{Uji aktivitas penghambatan polimerisasi heme secara in vitro \\ Hasil uji aktivitas menunjukkan bahwa} ekstrak etanol dari bunga matahari memiliki nilai $\mathrm{IC}_{50}$ lebih rendah, yaitu sebesar 160,10 $\mu \mathrm{g} / \mathrm{ml}$ dibandingkan dengan ekstrak daun sirih yang memiliki nilai sebesar 178,67 $\mu \mathrm{g} / \mathrm{ml}$, akan tetapi aktivitas penghambatan polimerisasi heme dari kulit batang kina yang mengandung alkaloid kuinin, yang sampai saat ini masih digunakan sebagai antimalaria, memiliki nilai $\mathrm{IC}_{50}$ yang lebih rendah yaitu sebesar 59,24 $\mu \mathrm{g} / \mathrm{ml}$ dibandingkan dengan kedua ekstrak uji. Dilaporkan klorokuin dan sejumlah antimalaria quinolin lainnya seperti amodiakuin, kuinidin, dan kuinin mempunyai kemampuan dalam penghambatan $\beta$-hematin. ${ }^{20}$

Peningkatan konsentrasi heme di dalam vakuola parasit dapat menimbulkan lisis membran parasit, sehingga plasmodium mempunyai mekanisme detoksifikasi heme, yaitu dengan mengubahnya menjadi senyawa hemozoin (pigmen malaria) yang inert bagi parasit. ${ }^{21,22}$ Polimerisasi heme untuk detoksifikasi heme oleh parasit malaria adalah proses yang penting bagi 
Tabel 2. Hasil uji aktivitas penghambatan polimerisasi heme secara in vitro ekstrak daun sirih dan sirih merah dibandingkan dengan ekstrak kulit batang kina

\begin{tabular}{lcccc}
\hline \multicolumn{1}{c}{ Sampel } & $\begin{array}{c}\text { Konsentrasi } \\
(\mu \mathrm{g} / \mathrm{ml})\end{array}$ & $\begin{array}{c}\mathrm{f} \text { (fraksi } \\
\beta \text {-hematin })\end{array}$ & $\%$ inhibisi & $\begin{array}{c}\mathrm{IC}_{50} \\
(\mu \mathrm{g} / \mathrm{ml})\end{array}$ \\
\hline Daun sirih & 31,25 & 0,9710 & 2,90 & 178,67 \\
& 62,5 & 0,8968 & 10,32 & \\
& 125 & 0,8645 & 13,55 & \\
& 250 & 0,2742 & 72,58 & \\
Daun bunga matahari & 500 & 0,0806 & 91,94 & 160,10 \\
& 31,25 & 0,838 & 16,17 & \\
& 62,5 & 0,785 & 21,45 & \\
Kulit batang kina & 125 & 0,746 & 25,41 & \\
& 250 & 0,604 & 39,60 & \\
& 500 & 0,050 & 95,05 & \\
& 31,25 & 0,9944 & 0,55 & \\
& 62,5 & 0,922 & 7,74 & \\
& 125 & 0,069 & 93,09 & \\
& 250 & 0,046 & 95,30 & \\
& 500 & 0,005 & 99,45 & \\
\hline
\end{tabular}

kehidupan parasit dan bersifat unik untuk Plasmodium intraeritrositik, dengan demikian pengujian aktivitas malaria dengan metode penghambatan polimerisasi heme menjadi salah satu pilihan untuk mencari senyawa antimalaria baru. ${ }^{23}$

\section{Simpulan}

Ekstrak daun sirih dan daun bunga matahari mempunyai aktivitas penghambatan polimerisasi heme dan dapat dikembangkan sebagai obat herbal untuk malaria. Ekstrak daun bunga matahari memiliki aktivitas penghambatan polimerisasi heme yang lebih baik dari ekstrak daun sirih.

\section{Pustaka}

1. Murray, C.J.L., Rosenfeld, L.C., Lim, S.S., Andrews, K.G., Foreman, K.J., Haring, D., Fullman, N., Naghavi, M., Lozano, R. \& Lopez, A.D. Global Malaria Mortality Between 1980-2010: a Systematic Analysis. The Lancet. 2012; 379 (9814): 413-431.

2. World Health Organization Malaria. Geneva, Switzerland. 2018; Available at http://www.who.int/mediacentre/ factsheets/fs094/en/ \{diakses tanggal : 25 Maret 2018].
3. Centers for Disease Control and Prevention (CDC). Where Malaria Occurs . 2017; Available at https://www.cdc.gov/ malaria/about/distribution.html [Diakses pada tanggal 9 Januari 2019].

4. World Health Organization, Guidelines for the treatment of malaria - 3rd edition, 2015; Available at https:// www.who.int/malaria/publications/ atoz/9789241549127/en/ [diakses tanggal 15 Desember 2018].

5. De Villiers, K., Egan, T.J., Recent Advances in the Discovery of HaemTargeting Drugs for Malaria and Schistosomiasis, Molecules, 2009; 14:2868-2887.

6. Kurosawa, Y., Dorn, A., Kitsuji-Shirane, M., Shimada, H., Satoh, T., Matile, H., Hofheinz, W., Masciadri, R., Kansy, M. \& Ridley, R.G., Hemeatin Polymerization Assay as a High-Throughput Screen for Identification of New Antimalarial Pharmacophores. Antimicrobial Agents and Chemeotherapy. 2000; 44 (10):26382644.

7. Hermanto, F, Yenny F, Lilis S A, Tri R S, Uji aktivitas antimalaria ekstrak etanol daun cocor bebek (Kalanchoe blossfeldiana Poelln.) pada Plasmodium 
falciparum 3D7. Kartika jurnal ilmiah farmasi, 2014; 2(2):54-58.

8. Ihwan K, S. H. A. Antimalarial Herbal Plants in Kupang, Indonesia. Biosaintifika: Journal of Biology \& Biology Education, 2017; 9(1):95-104.

9. Al-Adhroey, A.H. Antimalarial Activity of Methanolic Leaf Extract of Piper betle L. Molecules, MDPI, 2011;16(1):107-18.

10. Al-Adhroey, A.H.; Nor, Z.M.; AlMekhlafi, H.M.; Mahmud, R. Ethnobotanical study on some Malaysian anti-malarial plants: A community based survey. J. Ethnopharmacol. 2010;132:362-364.

11. Mutiah, R., Activity of Antimalarial Compounds from Ethyl Acetate Fraction of Sunflower Leaves (Helianthus annuus L.) against Plasmodium falciparum Parasites 3D7, Asian J. Pharm. Tech. 2017; 7(2):61-5.

12. Farnsworth, N.R. Biological and phytochemical screening of plants. Journal of Pharmaceutical Sciences, $1966 ; 55: 259-260$.

13. Huy, N. T., Uyen, D. T., Maeda, A., Trang, D. T., Oida, T., Harada, S., \& Kamei, K. Simple colorimetric inhibition assay of heme crystallization for high-throughput screening of antimalarial compounds. Antimicrobial agents and chemotherapy, 2006; 51(1):350-353.

14. Tu, Y. The discovery of artemisinin (qinghaosu) and gifts from Chinese medicine. Nat. Med. 2011; 17:12171220.
15. Klayman, D. Qinghaosu (artemisinin): An antimalarial drug from China. Science 1985; 228:1049.

16. Faurant C., From bark to weed: the history of artemisinin. Parasite. 2011;18(3): 2158.

17. Pan, Wen-Hui Xu, Xin-Ya Shi, Ni Tsang, Siu Wai Zhang, Hong-Jie. Antimalarial Activity of Plant Metabolites. International Journal of Molecular Sciences. 2018; 19:1382.

18. Egan, Timothy J., Kanyile K. Ncokazi. Quinoline Antimalarials Decrease the Rate of $\beta$-Hematin Formation. Journal of Inorganic Biochemistry, 2005; 99(7): $1532-1539$.

19. Pisciotta JM, Scholl PF, Shuman JL, Shualev V, Sullivan DJ. Quantitative characterization of hemozoin in Plasmodium berghei and vivax. Int J Parasitol Drugs Drug Resist. 2017;7(1):110-119.

20. Fong, K. Y., Wright, D. W. Hemozoin and antimalarial drug discovery. Future Medicinal Chemistry. 2013; 5(12):14371450.

21. Kurosawa, Y., Dorn, A., Kitsuji-Shirane, M., Shimada, H., Satoh, T., Matile, H., Hofheinz, W., Masciadri, R., Kansy, M. \& Ridley, R.G.. Hemeatin Polymerization Assay as a High-Throughput Screen for Identification of New Antimalarial Pharmacophores. Antimicrobial Agents and Chemeotherapy. 2000;. 44 (10):26382644. 